\title{
Seasonal changes in carbohydrates, cyclitols, and water relations of 3 field grown Eucalyptus species from contrasting taxonomy on a common site
}

\author{
Andrew Merchant ${ }^{1,2 *}$, Stefan K. ARndT ${ }^{2}$, Douglas M. Rowell ${ }^{2}$, Sabine Posch $^{2}$, \\ Andrew CALlister ${ }^{2}$, Michael TAUSZ ${ }^{2}$, Mark A. AdAMs ${ }^{1}$ \\ ${ }^{1}$ Faculty of Agriculture, Food and Natural Resources, University of Sydney, Sydney 2006, Australia \\ ${ }^{2}$ Department of Forest and Ecosystem Science, University of Melbourne, Water St, Creswick, Victoria 3363, Australia
}

(Received 20 March 2009; accepted 16 June 2009)

Keywords:

Eucalyptus /

water potential /

pressure volume /

osmotic adjustment

\begin{abstract}
- Alterations in plant chemistry underpin a suite of physiological adaptations to arid conditions. Qualitative and quantitative differences in leaf chemistry are found in the genus Eucalyptus correlating with physiological adaptation to aridity.

- Here we investigate seasonal water relations of three field grown eucalypt species grown at a common site known to differ in their ability to accumulate the cyclic sugar alcohol, quercitol.

- We show that quercitol contributes significantly to osmotic relations in field grown trees of Eucalyptus melliodora but is present only in trace amounts in E. rubida and E. obliqua.

- Measured concentrations of quercitol account for the difference in osmotic potentials between species and can be interpreted as a mechanism for adaptation to low water availability.
\end{abstract}

Mots-clés :

Eucalyptus /

potentiel hydrique /

pression volume /

ajustement osmotique
Résumé - Variations saisonnières des hydrates de carbone, des cyclitols et des relations hydriques chez 3 espèces d'Eucalyptus de taxonomie contrastée, en plein champ et poussant sur un site commun.

- Des altérations dans la chimie des plants soutiennent une série d'adaptations physiologiques à l'aridité. Des différences qualitatives et quantitatives dans la chimie des feuilles sont trouvées chez le genre Eucalyptus en corrélation avec les adaptations physiologiques à l'aridité.

- Ici, nous étudions les relations hydriques saisonnières de 3 espèces d'Eucalyptus de plein champ, poussant sur un site commun, connues pour être différentes au plan de leur capacité à accumuler le quercitol.

- Nous montrons que le quercitol contribue de manière significative aux relations osmotiques chez Eucalyptus melliodora mais est seulement présent à l'état de trace chez Eucalyptus rubida et Eucalyptus obliqua.

- Les concentrations de quercitol qui ont été mesurées rendent compte des différences de potentiel osmotique observées entre les espèces et peuvent être interprétées comme un mécanisme d'adaptation à la faible disponibilité en eau.

\section{INTRODUCTION}

Aridity is a major factor in shaping vegetation worldwide. This is particularly true for large parts of the Australian flora, including the genus Eucalyptus. Eucalypts are renowned for their tolerance to arid conditions; a feature considered a driving influence in the origins of the diversity of the more than

*Corresponding author: a.merchant@usyd.edu.au
600 species (e.g. Adams, 1996). The genus Eucalyptus is taxonomically divided into 13 subgenera of which Eucalyptus (formerly Monocalyptus, $\sim 110$ species) and Symphyomyrtus ( $\sim 500$ species) comprise the majority of species. Interand intra-specific variation in growth strategies under drought and/or salt exposure has been demonstrated in many screening experiments (Bell, 1999; Johansson et al., 1996; Niknam et al., 2000; Sun et al., 1993; van der Moezel et al., 1987; 1991; Zohar et al., 1998) highlighting the significance of species 
adaptation. Despite this variation, no precise physiological basis for these differences has been fully established (Bell et al., 1997).

A commonly observed physiological response to drought is the modification of internal osmotic potential (for review see Turner et al., 1980). For eucalypts, the adjustment of internal osmotic potential in response to saline and/or dry conditions has been demonstrated across many species (ClaytonGreene, 1983; Lemcoff et al., 1994; Li, 1998; Myers et al., 1986; Pita et al., 2001; Tuomela, 1997; White et al., 2000). Variation among eucalypt species in the capacity to modify osmotic potential has been proposed to explain differing salt (Grieve et al., 1999) and drought (Li, 1998) tolerances, leading to suggestions of its use as a selection criterion (Lemcoff et al., 1994; van der Moezel et al., 1991).

The cyclitol "quercitol" is commonly detected in species of Quercus (Passarinho et al., 2006; Popp et al., 1997) and may contribute to osmotic relations in some species of Eucalyptus (Merchant et al., 2005; 2006). Quercitol is found in significant concentrations in Eucalyptus spp. and is distributed in a clear taxonomic pattern (for example differences between subgenera), that correlates well with environmental adaptation (Merchant et al., 2007). Drought experiments using potted plants show that Eucalyptus spp. from more xeric environments accumulate quercitol in response to drought, whereas species from more mesic environments do not (Merchant et al., 2006). A field based study on E. astringens showed that quercitol can make a substantial contribution to osmotic adjustment in drought stressed trees and that it occurs in all tree organs (Arndt et al., 2008) and a further pot study confirmed that quercitol-accumulating Eucalyptus spp. differ in their water relations from non-accumulating species (Merchant et al., 2007).

It is as yet unknown whether such differences in quercitol accumulation are found in the field among species inhabiting the same site, and whether related differences in water relations, that are potentially significant in drought tolerance strategies, are also present under field conditions. A number of studies that have investigated inter-specific variation of osmotic potential in eucalypt species e.g. E nitens and E. globulus (White et al., 1996), E. behriana and E. polyanthermos (Prior et al., 1999), E. microcarpa (Clayton-Greene, 1983; Prior et al., 1999), E. melliodora (Clayton-Greene, 1983) and E. camaldulensis, E. grandis, E. viminalis and E. tereticornis (Lemcoff et al., 1994) and eucalypt hybrids (Callister et al., 2006). However, only White et al. (2000) has investigated the physiology of eucalypt species from contrasting "chemo-taxonomic" groups indentified previously (Merchant et al., 2007). Based upon physiological assessments (water potentials, gas exchange and osmotic relations), results of that study suggested that four eucalypt species (E. camaldulensis, E. saligna, E. melliodora and E. platypus) possess contrasting mechanisms for tolerating water deficit.

Despite the relatively low number of investigations, and the obvious limitations of cross-study comparisons, there is a scarcity of studies that (1) concurrently investigate differing chemo-taxonomic groups within the genus Eucalyptus (2) employ both physiological and chemical based techniques to in- vestigate osmotic relations and (3) conduct these studies in the field. The present study is designed to verify our earlier results on potted seedlings on large field grown trees. To that end, we studied three different Eucalyptus species, Eucalyptus obliqua (L. Her'), E. rubida (Deane and Maiden), and E. melliodora (Cunn. ex Schauer), growing in a mixed stand in the field. E. obliqua and E. rubida belong to taxonomic groups that, according to earlier studies, do not accumulate quercitol (Merchant et al., 2006; 2007). E. melliodora, on the other hand, has been shown to accumulate quercitol, especially in response to drought stress (Merchant et al., 2006).

We analysed cyclitol and carbohydrate contents in leaves, measured total osmolality of the cell sap, and assessed osmotic relations using pressure volume curves to test the following hypotheses: (1) E. melliodora leaves contain more quercitol than the other species (where we would expect very low or no detectable concentrations of quercitol); (2) there is a seasonal difference in water and osmotic relations (osmotic adjustment) in the studied species; (3) E. melliodora shows increased resilience to the effects of water deficit compared to E. obliqua and $E$. rubida as observed in leaf level water relations.

\section{MATERIAL AND METHODS}

\subsection{Sampled trees}

We selected individuals of the three species Eucalyptus melliodora, E. rubida, and E. obliqua in the Long Point Flora Reserve, situated approximately $20 \mathrm{~km}$ north east of Ballarat, Victoria, Australia $\left(37.42^{\circ} \mathrm{S}, 143.88^{\circ} \mathrm{E}\right)$. The selection encompasses contrasting taxonomical classification, in particular representing major subgenera and series classifications.

\subsection{Site characteristics}

Trees used for this investigation grew in a mixed stand covering approximately $150 \mathrm{~m}^{2}$. Trees were approximately $30 \mathrm{y}$ of age, each reaching $20 \mathrm{~m}$ in height. Slope on this area was less than $2 \%$ with no notable aspect. The soil is a heavy clay with a high amount of quartz that is characteristic of the region. A shallow $(<2 \mathrm{~cm})$ layer of humus is present with little water holding capacity. The climate is Mediterranean with main rainfall during winter and an annual average of $742 \mathrm{~mm}$. Average maximum and minimum temperature at the site is $17.9^{\circ} \mathrm{C}$ and $6.6^{\circ} \mathrm{C}$ respectively.

\subsection{Experimental design}

Twelve trees from each species were numbered to ensure the consistent sampling of individuals both in the winter and summer sampling periods. Trees were distributed in a mixed arrangement with no apparent correlation to any environmental variable. Trees were sampled at dawn on the 23rd February 2005 (summer) and the 24th August 2005 (winter). At each sampling date, leaf predawn water potential was measured and leaf samples taken for pressure volume analysis, chemical analysis and measures of leaf water status. All samples were collected from leaves with full sun exposure in the mid to upper canopy. 
Table I. Leaf predawn water potential $\left(\Psi_{\mathrm{p}}\right)$ and relative water content (RWC) during winter (July) and summer (February) for 3 field grown Eucalyptus species. $p$ values represent seasonal differences between measurements. Post hoc grouping was performed using Tukey's HSD. Season significance was obtained using ANOVA and Fishers LSD tests.

\begin{tabular}{|c|c|c|c|c|c|c|c|}
\hline \multirow[t]{2}{*}{ Species } & \multicolumn{2}{|c|}{ Winter } & \multirow{2}{*}{$\begin{array}{l}\text { Species post hoc } \\
\text { groups }\end{array}$} & \multicolumn{2}{|c|}{ Summer } & \multirow{2}{*}{$\begin{array}{l}\text { Species post hoc } \\
\text { groups }\end{array}$} & \multirow[t]{2}{*}{ Season significance } \\
\hline & $\bar{x}$ & $\mathrm{se}$ & & $\overline{\bar{x}}$ & $\mathrm{se}$ & & \\
\hline$\Psi_{\text {pdwn }}(\mathrm{Mpa})$ & & & & & & & \\
\hline E. obliqua & -0.381 & 0.030 & $\mathrm{a}$ & -0.642 & 0.041 & $\mathrm{a}$ & 0.000 \\
\hline E. rubida & -0.240 & 0.036 & $\mathrm{a}$ & -1.063 & 0.127 & b & 0.000 \\
\hline $\begin{array}{l}\text { E. melliodora } \\
\text { RWC }(\%)\end{array}$ & -0.683 & 0.212 & $\mathrm{~b}$ & -1.158 & 0.051 & $\mathrm{~b}$ & 0.000 \\
\hline E. obliqua & 87.727 & 1.321 & a & 94.279 & 0.487 & $\mathrm{a}$ & 0.000 \\
\hline E. rubida & 88.747 & 1.113 & $\mathrm{a}$ & 90.459 & 0.944 & $\mathrm{~b}$ & 0.253 \\
\hline E. melliodora & 94.292 & 0.718 & $\mathrm{~b}$ & 91.128 & 0.829 & $\mathrm{~b}$ & 0.008 \\
\hline
\end{tabular}

\subsection{Leaf water characteristics}

In both winter and summer, predawn shoot water potential $\left(\psi_{\mathrm{p}}\right)$ of each tree was measured using a Scholander pressure bomb (PMS Corvallis USA) (Scholander et al., 1965). Leaf relative water contents (RWC) were determined gravimetrically on shoots collected at predawn. Three leaves from each plant were removed, sliced into $5 \mathrm{~mm}$ sections and weighed (fresh weight). These were then placed in deionised water at $4{ }^{\circ} \mathrm{C}$ for $12 \mathrm{~h}$ to allow full hydration. Leaf samples were then lightly blotted dry with tissue paper and re-weighed (saturated weight). Samples were then dried at $36^{\circ} \mathrm{C}$ for $48 \mathrm{~h}$ and reweighed (dry weight). Relative water content was calculated based upon the formula:

$$
\begin{aligned}
\text { RWC }= & (\text { Fresh weight }- \text { Dry weight }) /(\text { Saturated weight } \\
& - \text { Dry weight }) \times 100 .
\end{aligned}
$$

Osmotic potential at full turgor $\left(\pi_{100}\right)$, osmotic potential at turgor loss point $\left(\pi_{0}\right)$, relative water content at turgor loss point $\left(\mathrm{RWC}_{0}\right)$, and bulk elastic modulus $(\varepsilon)$ were determined using pressure volume (PV) curve analysis (Turner, 1988; Tyree et al., 1972). $p V$ curves were determined for 6 trees for each species at each sampling period. Shoots were initially re-hydrated in the dark for $3 \mathrm{~h}$.

\subsection{Leaf chemical characteristics (organic and inorganic solutes)}

Samples collected for chemical analysis consisted of several first fully expanded (FFE) leaves on terminal branchlets. Samples were placed in $2 \mathrm{~mL}$ micro-tubes and transferred immediately to liquid nitrogen. In the laboratory, samples were briefly irradiated (30 s) in a standard $650 \mathrm{~W}$ microwave oven and then oven dried overnight at $85^{\circ} \mathrm{C}$. Samples were stored at $-86^{\circ} \mathrm{C}$ awaiting analysis.

Soluble carbohydrates were extracted according to Adams et al. (2005) via a phase separation technique using $1 \mathrm{~mL}$ of hot methanolchloroform-water (MCW, 12:5:3).

Carbohydrates were separated and quantified using gas chromatography according to the technique used previously (Merchant et al., 2006). Briefly, $60 \mu \mathrm{L}$ of extracted sample was dried and then suspended in $400 \mu \mathrm{L}$ of anhydrous pyridine to which $50 \mu \mathrm{L}$ trimethylchlorosilane (TMCS)/bis-trimethylsilyl-trifluoroacetamide mix (1:10, Sigma Aldrich) was added. Samples were incubated for $1 \mathrm{~h}$ at $75^{\circ} \mathrm{C}$ and analysed by gas chromatography (GC) within $24 \mathrm{~h}$.
GC analysis was performed using a Shimadzu 17A series gas chromatograph using a DB1 $(30 \mathrm{~m})$ column. Split injection was made at $300{ }^{\circ} \mathrm{C}$ with an initial oven temperature program of $60{ }^{\circ} \mathrm{C}$ for $2 \mathrm{~min}$ ramping to $300{ }^{\circ} \mathrm{C}$ at $10{ }^{\circ} \mathrm{C} / \mathrm{min}$ and maintained for $10 \mathrm{~min}$. Column flow rate was maintained at $1.5 \mathrm{~mL}$ per min. Peak integration was made using Class VP analysis software (Shimadzu Corporation Limited). Concentrations of organic solutes in tissue water were calculated based upon the amount of water $\left(\mathrm{g}^{-1}\right.$ dry weight) determined by RWC measurements.

Measurements of total cellular osmolality were determined by freeze point depression from hot water extracts. Approximately $40 \mathrm{mg}$ of dried ground leaf tissue (as prepared above) was placed in a $2 \mathrm{~mL}$ screw-cap microtube to which $1 \mathrm{ml}$ of hot water $\left(80^{\circ} \mathrm{C}\right)$ was added. Samples were incubated for $30 \mathrm{~min}$ at $80{ }^{\circ} \mathrm{C}$, and agitated twice during this period. Samples were left to cool to room temperature, centrifuged $(11.400 \times g)$ and the top $800 \mu \mathrm{L}$ removed to a clean microtube. Osmolality of the solution was measured using an OSMOMAT 030 cryoscopic osmometer (Gonotec, Germany). Leaf water osmolality was calculated from values obtained by freeze point depression osmometry combined with RWC values obtained in the field.

\subsection{Statistical analysis}

Differences in measured parameters between species and season were analysed by analysis of variance using "Statistica" analytical software (Version 6 StatSoft, Tulsa, OK). $P$ values were calculated using Fisher's least squared difference post-hoc test mean values.

\section{RESULTS}

\subsection{Leaf water characteristics}

Predawn water potentials $\left(\psi_{\mathrm{p}}\right)$ showed significant albeit moderate reductions from winter to summer in all species (Tab. I). E. melliodora had the lowest $\psi_{\mathrm{p}}$ in both winter and summer. E. rubida showed the largest reduction in $\psi_{\mathrm{p}}$ of the three species.

E. melliodora was the only species to show significant reductions in RWC from winter to summer (Tab. I). E. obliqua showed a significant increase in RWC from winter to summer that was, in summer, significantly higher than those of the two 
Table II. Osmotic potential at full turgor $\left(\pi_{100}\right)$, osmotic potential at turgor loss point $\left(\pi_{0}\right)$, relative water content at turgor loss point $(\mathrm{RWC})$ and mean bulk elastic modulus ( $\varepsilon$ ) for 3 species of Eucalyptus during winter (date) and summer (date) sampling periods. Post hoc grouping was performed using Tukey's HSD. Season significance was obtained using ANOVA and Fishers LSD tests.

\begin{tabular}{|c|c|c|c|c|c|c|c|}
\hline \multirow[t]{2}{*}{ Species } & \multicolumn{2}{|c|}{ Winter } & \multirow{2}{*}{$\begin{array}{l}\text { Species post hoc } \\
\text { groups }\end{array}$} & \multicolumn{2}{|c|}{ Summer } & \multirow{2}{*}{$\begin{array}{l}\text { Species post hoc } \\
\text { groups }\end{array}$} & \multirow[t]{2}{*}{ Season significance } \\
\hline & $\bar{x}$ & $\mathrm{se}$ & & $\overline{\bar{x}}$ & $\mathrm{se}$ & & \\
\hline$\pi_{100}(\mathrm{MPa})$ & & & & & & & \\
\hline E. obliqua & -1.856 & 0.035 & $\mathrm{a}$ & -1.800 & 0.036 & $\mathrm{a}$ & 0.101 \\
\hline E. rubida & -1.986 & 0.116 & $\mathrm{a}$ & -1.871 & 0.038 & $\mathrm{a}$ & 0.188 \\
\hline $\begin{array}{l}\text { E. melliodora } \\
\pi_{0}(\mathrm{MPa})\end{array}$ & -2.350 & 0.059 & $\mathrm{~b}$ & -2.784 & 0.182 & $\mathrm{~b}$ & 0.026 \\
\hline E. obliqua & -2.156 & 0.034 & $\mathrm{a}$ & -2.091 & 0.065 & $\mathrm{a}$ & 0.109 \\
\hline E. rubida & -2.328 & 0.113 & $\mathrm{a}$ & -2.203 & 0.052 & $\mathrm{a}$ & 0.171 \\
\hline $\begin{array}{l}\text { E. melliodora } \\
\mathrm{RWC}_{0}(\%)\end{array}$ & -2.837 & 0.052 & $\mathrm{~b}$ & -3.360 & 0.221 & $\mathrm{~b}$ & 0.025 \\
\hline E. obliqua & 91.510 & 1.137 & $\mathrm{a}$ & 88.600 & 0.927 & a & 0.041 \\
\hline E. rubida & 87.660 & 0.858 & a & 88.500 & 0.316 & a & 0.193 \\
\hline $\begin{array}{l}\text { E. melliodora } \\
\varepsilon\end{array}$ & 87.900 & 1.100 & $\mathrm{a}$ & 85.700 & 1.546 & $\mathrm{a}$ & 0.140 \\
\hline E. obliqua & 8.469 & 1.259 & $\mathrm{a}$ & 11.901 & 2.376 & a & 0.119 \\
\hline E. rubida & 7.017 & 1.072 & $a b$ & 6.674 & 1.082 & $a b$ & 0.414 \\
\hline E. melliodora & 4.429 & 0.389 & $\mathrm{~b}$ & 3.233 & 0.464 & $\mathrm{~b}$ & 0.042 \\
\hline
\end{tabular}

other species. RWC for all species were maintained above the calculated values for $\mathrm{RWC}_{0}$ except for E. obliqua in the winter period $\left(\mathrm{RWC}=87.73, \mathrm{RWC}_{0}=91.51\right)$.

From winter to summer, significant reductions in the osmotic potential at full turgor $\left(\pi_{100}\right)$ and the osmotic potential at turgor loss point $\left(\pi_{0}\right)$ were detected only in E. melliodora trees, with no significant changes in these parameters in the other species (Tab. II). $\pi_{100}$ and $\pi_{0}$ was significantly lower in E. melliodora trees compared to the other species in both seasons (Tab. II).

$\mathrm{RWC}_{0}$ significantly changed only in E. obliqua (Tab. II). $\mathrm{RWC}_{0}$ was found to average above $85 \%$ in all species regardless of season. These values illustrate that the trees were functioning only just above this point (Tabs. I and II). From winter to summer, the elastic modulus $(\varepsilon)$ significantly decreased in E. melliodora, but not for E. rubida and obliqua (Tab. II). Values of $\varepsilon$, regardless of season, displayed levels of elasticity according to the pattern: E. melliodora $<$ E. rubida $<$ E. obliqua.

\subsection{Leaf chemical properties}

Osmolality increased significantly in all species between winter and summer (Fig. 1). E. melliodora had higher osmolality than $E$. obliqua during both winter and summer whilst $E$. rubida had the greatest osmolality in summer. Of the three eucalypt species, increases in tissue osmolality were the largest in E. rubida.

Quercitol concentrations over $100 \mathrm{mmol} \mathrm{kg}^{-1}$ leaf water were obtained from E. melliodora leaves. Quercitol clearly dominated the soluble carbon fraction for leaves of this species. Quercitol was also detected in E. rubida in the summer period, at concentrations of approximately $10 \mathrm{mmol} \mathrm{kg}$ leaf water whilst two samples of E. obliqua were found to contain quercitol (in winter), and then only in trace amounts.
Concentrations of fructose, myo-inositol, sorbitol and sucrose all significantly increased in E. melliodora and E. rubida trees from winter to summer (Fig. 1). Similarly, significant increases were observed in glucose levels only in E. rubida. For E. obliqua, fructose was the only measured metabolite that increased from winter to summer. Levels of myo-inositol and sucrose declined significantly from winter to summer.

\section{DISCUSSION}

In many plants, carbohydrates and polyols are the major soluble constituents of leaf tissues and are often linked with a role in osmoregulation (e.g. Koppenaal et al., 1991; McManus et al., 2000; Rajam et al., 1998; Sacher et al., 1985; Wingler, 2002). Previous studies quantifying soluble carbohydrates in Eucalyptus species in the field are rare, probably because the diversity of carbohydrates and polyols makes their comprehensive ("metabolomic") analysis difficult. Our first hypothesis was that leaves of E. melliodora would contain large concentrations of quercitol. In agreement with earlier studies on seedlings (Merchant et al., 2006) and a general field survey on larger trees (Merchant et al., 2007), leaves of $E$. melliodora contained quercitol at concentrations of the order of $100 \mathrm{mmol} \mathrm{L}^{-1}$ based on leaf water content at full turgor. Leaves of E. obliqua and E. rubida contained more than an order of magnitude less quercitol. Concurrently, E. melliodora generally exhibited more negative water potentials and more negative osmotic potentials than the other two species. According to the Van't Hoff equation (at $20^{\circ} \mathrm{C}$ ), the presence of quercitol in E. melliodora in fully hydrated leaves would account for about $-0.26 \mathrm{MPa}$, which would explain most of the difference from the other two species in osmotic potentials and predawn water potentials.

For E. melliodora, quercitol contributed to about $10 \%$ of the osmolality measured in an aqueous extract of the leaves. 


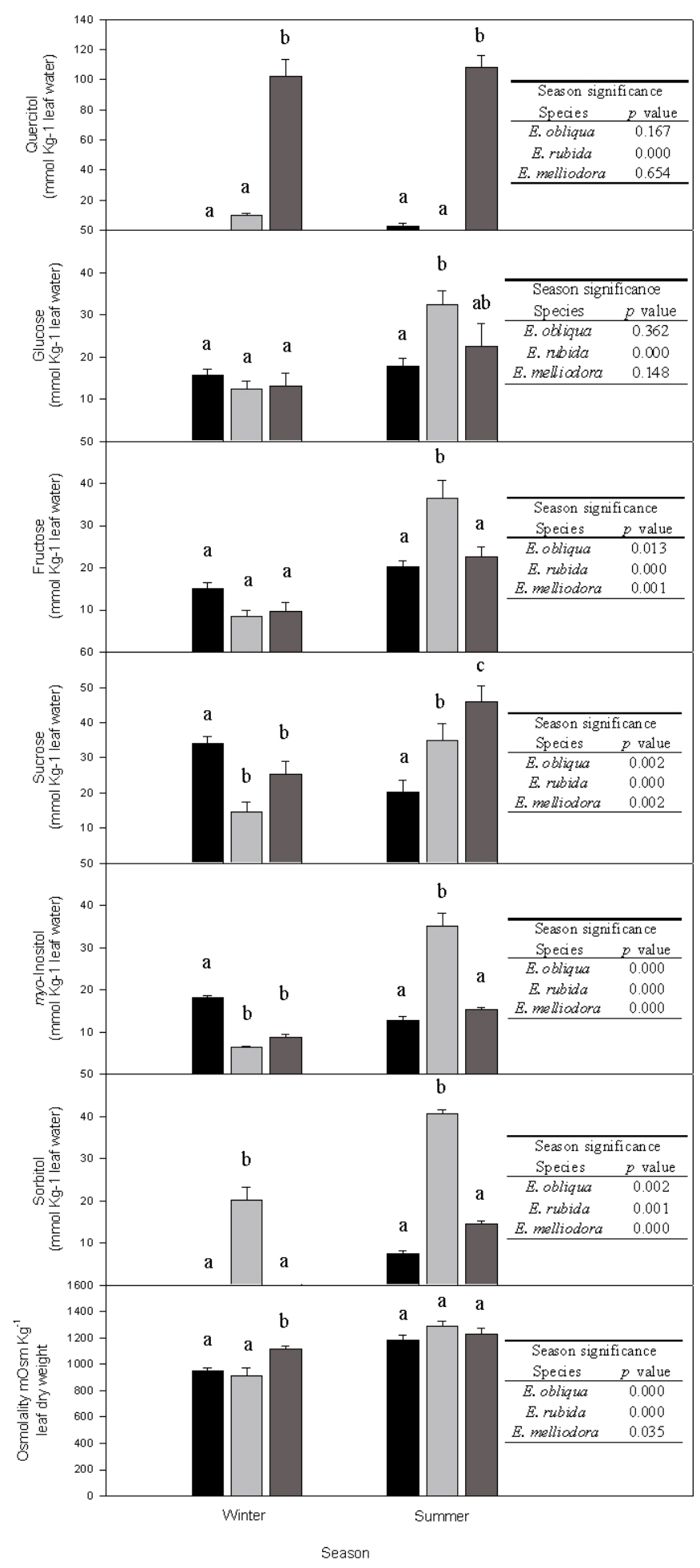

Figure 1. Concentration of the major carbon based solutes (mmol $\mathrm{Kg}^{-1}$ leaf water) in leaves of E. obliqua (black) E. rubida (light) and E. melliodora, (mid grey) during both winter (July) and summer (February). Means and standard errors of 6 replicate trees are shown per species and sampling date. Post hoc grouping was performed using Tukey's HSD. Season significance was obtained using ANOVA and Fishers LSD tests.
Quercitol concentrations were more than twice those of the second most abundant carbohydrate, sucrose, with all measured carbohydrates and cyclitols contributing close to $20 \%$ of the total osmolality. It is noteworthy that quercitol was found in all species. Hence, species differences are most probably not due to the presence or absence of any specific biosynthetic pathway, but more likely due to different regulation or expression of these pathways.

In our second hypothesis, we addressed the seasonal changes in water relations and solute concentrations. Predawn water potentials measured in this study fall within the values commonly obtained from field based studies in Eucalyptus (Myers et al., 1997; White et al., 1999; 2000; Zubrinich et al., 2000). The slight reductions in predawn water potential $\Psi$ of $0.3-0.5 \mathrm{MPa}$ observed for all species from winter to summer may indicate mild water deficit at this site in summer, as could be expected from the Mediterranean rainfall patterns. Previous investigations into field grown eucalypts have investigated trees often showing larger variations in $\Psi$, probably corresponding to more severe drought stress (e.g. Arndt et al., 2008; Merchant et al., 2007; White et al., 2000). Our results offer an opportunity to investigate the potential acclimatory responses of plant metabolism to moderate seasonal fluctuations in water availability.

In general, pressure volume curves remain one of the reference methods of determining in vivo osmotic potentials (Turner et al., 1980; Tyree et al., 1972). Our measured total osmolality reflects extractable solutes as opposed to in vivo osmotically active solutes. An earlier comparison of these methods showed that osmolality measured on hot water extracts does not necessarily correlate well with direct measurements on the expressed cell sap or results from the $p V$ curves (Callister et al., 2006). In addition, a decrease in water potentials may reflect decreases in soil water potentials, but may also be ascribed to changes in the osmotic potential (osmotic adjustment) of leaf tissues (e.g. Turner et al., 1980). Measurements of total osmolality in tissue extracts did indicate an increase in osmotically active solutes in leaves of all three species from winter to summer, but $p V$ curve analyses only showed a decrease in osmotic potential for E. melliodora. This discrepancy could be partly reconciled by increases in relative water content from winter to summer diluting the solutes thus reducing their effects on osmotic potential. Measures of $\varepsilon$ (the elastic modulus of the tissues) are higher in both $E$. obliqua and $E$. rubida, corresponding to reduced maximum elasticity. The identification of turgor loss point in these species (due to the larger influence of $\varepsilon$ ) resulted in higher variability on measures of $\pi_{100}$ and $\pi_{0}$ reducing our ability to distinguish changing patterns of these parameters.

Although osmotic adjustment from winter to summer was only clearly demonstrated for E. melliodora (according to $p V$ curve analysis), we observed significant differences in cyclitol and carbohydrate concentrations between winter and summer in all species, and for most compounds. In both E. melliodora and E. rubida, the low molecular weight sugars - glucose, fructose, and sucrose - as well as the sugar alcohols - myoinositol and sorbitol - all increased in concentration in summer, most of them by at least $10 \mathrm{mmol} \mathrm{L}^{-1}$ leaf water. They 
thus contributed about $30-50 \%$ to an increase in total extractable osmotically active solutes. The remainder of the osmotic potential is most likely contributed by ions (organic and inorganic), amino acids, or other low molecular weight water soluble compounds such as thiols. In E. obliqua, on the other hand, changes in these compounds were small, and often in opposite directions. For example, while fructose concentrations increased slightly (but significantly), sucrose concentrations decreased, resulting in a net change close to zero. Nevertheless, a significant increase in total extractable osmotically active solutes was also observed in E. obliqua, which must be attributed to other osmotically active compounds.

We can only speculate on the reasons for such species specific differences in seasonal changes in solutes. Some studies support the hypothesis by (Turner and Jones, 1980) that osmotic adjustment arises from an accumulation of solutes as a result of the continuation of photosynthesis after the cessation of leaf growth (sink limitation). Keiper et al. (1998) demonstrated this pattern in glucose and sucrose for E. microcorys however, the same did not apply to fructose. Similarly, the work of Stoneman et al. (1994) supported the role of excess photosynthetic products in lowering osmotic potential in $E$. marginata seedlings. If such an imbalance of sink (growth or storage) to source (photosynthates) contributes to the increase of solutes in summer, then fundamental differences between species seem to exist in carbohydrate production and allocation patterns.

In our third hypothesis we state that E. melliodora would show marked differences from the other species in water relations and seasonal acclimation strategy. This was true in that E. melliodora showed osmotic adjustment and generally more negative water potentials and osmotic potentials. However, whilst quercitol concentrations may explain the more negative osmotic potentials in E. melliodora, there was no apparent relationship to seasonal adjustment, because quercitol concentrations were constant and did not change from winter to summer in this species. These results support previous investigations (Merchant et al., 2006) suggesting that quercitol concentrations are a constitutive property rather than variable according to seasonal water deficit.

We must also consider roles other than in osmotic regulations for quercitol (and cyclitols generally). Cyclitols have been shown to possess osmoprotective roles both in vitro (Orthen et al., 2000) and hypothesised to function in vivo (Paul et al., 1989) based upon their subcellular localisation. Orthen et al. (1994) suggested that these compounds may play a role in scavenging reactive oxygen species (ROS) formed preferentially under conditions of excess excitation energy in the photosynthetic apparatus, an unavoidable situation if plants close their stomata to avoid water loss during the day (e.g. Flexas et al., 2002). Carbohydrates and cyclitols may also be involved in other forms of diversion of excess photochemical energy (Hare et al., 1998) and maintenance of redox potential. Carbohydrates and poloyls close association with common cellular processes, low molecular weights, and low toxicity, renders them excellent candidates as stable osmotica in plant tissues.

In conclusion, our study confirmed differences between $E u$ calyptus species in the presence of high quercitol concentra- tions and coincident acclimation of water relations to seasonal changes under field conditions. However, the link between quercitol and water relations was less obvious. Quercitol concentrations did not change seasonally, which leaves the role of quercitol in seasonal osmotic adjustment as unresolved. Quercitol contributes to generally more negative water potentials and osmotic potentials in field grown E. melliodora, which may be interpreted as a constitutively present adaptation to lower water availability.

Acknowledgements: The authors wish to thank Parks Victoria for allowing access to the field site and the anonymous reviewers for their comments on the manuscript.

\section{REFERENCES}

Adams M.A., 1996. Distribution of eucalypts in Australian landscapes: landforms, soils, fire and nutrition. In: Attiwill P.M., Adams M.A. (Eds.), Nutrition of eucalypts, CSIRO Australia, pp. 61-76.

Adams M.A., Richter A., Hill A.K., and Colmer T.D., 2005. Salt tolerance in Eucalyptus spp.: identity and response of putative osmolytes. Plant Cell Environ. 28: 772-787.

Arndt S.K., Livesley S., Merchant A., Bleby T., and Grierson P., 2008. Quercitol and osmotic adaptation of field grown Eucalyptus under seasonal drought stress. Plant Cell Environ. 31: 915-924.

Bell D.T., 1999. Australian trees for the rehabilitation of waterlogged and salinity-damaged landscapes. Aust. J. Bot. 47: 697-716.

Bell D.T. and Williams J.E., 1997. Eucalypt ecophysiology, In: Williams J., Woinarsky J. (Eds.), Eucalypt Ecology, Cambridge University Press, Cambridge.

Callister A.N. and Adams M.A., 2006. Water stress impacts on respiratory rate, efficiency and substrates, in growing and mature foliage of Eucalyptus spp. Planta 224: 680-691.

Callister A.N., Arndt S.K., and Adams M.A., 2006. Comparison of four methods for measuring osmotic potential in tree leaves. Physiol. Plant. 127: 383-392.

Clayton-Greene K.A., 1983. The tissue water relationships of Callitris columellaris, Eucalyptus melliodora and Eucalyptus microcarpa investigated using the pressure-volume technique. Oecologia 57: 368-373.

Flexas J. and Medrano H., 2002. Energy dissipation in C-3 plants under drought. Funct. Plant Biol. 29: 1209-1215.

Grieve C.M. and Shannon M.C., 1999. Ion accumulation and distribution in shoot components of salt- stressed Eucalyptus clones. J. Am. Soc. Hortic. Sci. 124: 559-563.

Hare P.D., Cress W.A., and Van Staden J., 1998. Dissecting the roles of osmolyte accumulation during stress. Plant Cell Environ. 21: 535553.

Johansson S. and Tuomela K., 1996. Growth of 16 provenances of Eucalyptus microtheca in a regularly irrigated plantation in eastern Kenya. For. Ecol. Manage. 82: 11-18.

Keiper F.J., Chen D.M., and De Filippis L.F., 1998. Respiratory, photosynthetic and ultrastructural changes accompanying salt adaptation in culture of Eucalyptus microcorys. J. Plant Physiol. 152: 564-573.

Koppenaal R.S., Tschaplinski T.J., and Colombo S.J., 1991. Carbohydrate accumulation and turgor maintenance in seedling shoots and roots of 2 boreal conifers subjected to water stress. Can. J. Bot./Rev. Can. Bot. 69: 2522-2528.

Lemcoff J.H., Guarnaschelli A.B., Garau A.M., Basciauli M.E., and Ghersa C.M., 1994. Osmotic adjustment and its use as a selection criterion in Eucalyptus seedlings. Can. J. For. Res. 24: 2404-2408. 
Li C.Y., 1998. Some aspects of leaf water relations in four provenances of Eucalyptus microtheca seedlings. For. Ecol. Manage. 111: 303-308.

McManus M.T., Bieleski R.L., Caradus J.R., and Barker D.J., 2000. Pinitol accumulation in mature leaves of white clover in response to a water deficit. Environ. Exp. Bot. 43: 11-18.

Merchant A. and Adams M.A., 2005. Stable osmotica in Eucalyptus spathulata - responses to salt and water deficit stress. Funct. Plant Biol. 32: 797-805.

Merchant A., Adams M.A., Richter A., and Popp M., 2006. A metabolite approach provides functional links among eucalypt taxonomy, physiology and evolution. Phytochemistry 67: 402-408.

Merchant A., Ladiges P.Y., and Adams M.A., 2007. Quercitol links the physiology, taxonomy and evolution of 279 eucalypt species. Glob. Ecol. Biogeogr. 16: 810-819.

Merchant A., S.K A., A.N C., and M.A A., 2007. Contrasting physiological responses to water deficit in six Eucalyptus species. Ann. Bot. 100: $1507-1515$.

Merchant A., Tausz M., Arndt S.K., and Adams M.A., 2006. Cyclitols and carbohydrates in leaves and roots of 13 Eucalyptus species suggest contrasting physiological responses to water deficit. Plant Cell Environ. 29: 2017-2029.

Myers B.A., Duff G.A., Eamus D., Fordyce I.R., O'grady A., and Williams R.J., 1997. Seasonal variation in water relations of trees of differing leaf phenology in a wet-dry tropical savanna near Darwin, northern Australia. Aust. J. Bot. 45: 225-240.

Myers B.A. and Neales T.F., 1986. Osmotic adjustment, induced by drought, in seedlings of three Eucalyptus species. Austr. J. Plant Physiol. 13: 597-603.

Niknam S.R. and McComb J., 2000. Salt tolerance screening of selected Australian woody species - a review. For. Ecol. Manage. 139: 1-19.

Orthen B. and Popp M., 2000. Cyclitols as cryoprotectants for spinach and chickpea thylakoids. Environ. Exp. Bot. 44: 125-132.

Orthen B., Popp M., and Smirnoff N., 1994. Hydroxyl radical scavenging properties of cyclitols, Proceedings of the Royal Society of Edinburgh Section B. Biological Sciences 102: 269-272.

Passarinho J.A.P., Lamosa P., Baeta J.P., Santos H., and Ricardo C.P.P., 2006. Annual changes in the concentration of minerals and organic compounds of Quercus suber leaves. Physiol. Plant. 127: 100-110.

Paul M.J. and Cockburn W., 1989. Pinitol, a compatible solute in Mesembryanthemum crystallinum L? J. Exp. Bot. 40: 1093-1098.

Pita P. and Pardos J.A., 2001. Growth, leaf morphology, water use and tissue water relations of Eucalyptus globulus clones in response to water deficit. Tree Physiol. 21: 599-607.

Popp M., Lied W., Bierbaum U., Gross M., Grosse-Schulte T., Hams S., Oldenettel J., Schuler S., and Wiese J., 1997. Cyclitols-stable osmotica in trees. In: Rennenberg H., Eschrich W., and Ziegler H. (Eds.), Trees - Contributions to modern tree physiology, Backhuys Publ., Leiden, pp. 257-270.

Prior L.D. and Eamus D., 1999. Seasonal changes in leaf water characteristics of Eucalyptus tetrodonta and Terminalia ferdinandiana saplings in a northern Australian savanna. Aust. J. Bot. 47: 587-599.

Rajam M.V., Dagar S., Waie B., Yadav J.S., Kumar P.A., Shoeb F., and Kumria R., 1998. Genetic engineering of polyamine and carbohydrate metabolism for osmotic stress tolerance in higher plants. J. Biosci. 23: 473-482.
Sacher R.F. and Staples R.C., 1985. Inositol and sugars in adaption of tomato to salt. Plant Physiol. 77: 206-210.

Scholander P.F., Hammel E.D., Bradstreet E.D., and Hemmingsen E.A., 1965. Sap pressure in vascular plants, negative hydrostatic pressure can be measured in plants. Science 148: 339-346.

Stoneman G.L., Turner N.C., and Dell B., 1994. Leaf growth, photosynthesis and tissue water relations of greenhouse-grown Eucalyptusmarginata seedlings in response to water deficits. Tree Physiol. 14: 633-646.

Sun D. and Dickinson G., 1993. Responses to salt stress of 16 Eucalyptus species, Grevillea-robusta, Lophostemon-confertus and Pinus-caribaea Var hondurensis. For. Ecol. Manage. 60: 1-14.

Tuomela K., 1997. Leaf water relations in six provenances of Eucalyptus microtheca: A greenhouse experiment. For. Ecol. Manage. 92: 1-10.

Turner N.C., 1988. Measurement of plant water status by the pressure chamber technique. Irrigation Science 9: 289-308.

Turner N.C. and Jones M.M., 1980. Turgor maintenance by osmotic adjustment: A review and evaluation. In: Turner N.C., Kramer P.J. (Eds.), Adaptation of plants to water and high temperature stress, Wiley-InterScience, New York, pp. 155-172.

Turner N.C. and Long M.J., 1980. Errors arising from rapid water-los in the measurement of leaf water potential by the pressure chamber technique. Austr. J. Plant Physiol. 7: 527-537.

Tyree M.T. and Hammel H.T., 1972. Measurement of turgor pressure and water relations of plants by pressure-bomb technique. J. Exp. Bot. 23: $267-282$.

Van der Moezel P.G. and Bell D.T., 1987. Comparitive seedling salt tolerance of several Eucalyptus and Melaleuca species from Western Australia. Austr. For. Res. 17: 151-158.

Van der Moezel P.G., Pearcepinto G.V.N., and Bell D.T., 1991. Screening for salt and waterlogging tolerance in Eucalyptus and Melaleuca species, For. Ecol. Manage. 40: 27-37.

White D.A., Beadle C.L., Sands P.J., Worledge D., and Honeysett J.L., 1999. Quantifying the effect of cumulative water stress on stomatal conductance of Eucalyptus globulus and Eucalyptus nitens: a phenomenological approach. Austr. J. Plant Physiol. 26: 17-27.

White D.A., Beadle C.L., and Worledge D., 1996. Leaf water relations of Eucalyptus globulus ssp. globulus and E. nitens: Seasonal, drought and species effects. Tree Physiol. 16: 469-476.

White D.A., Turner N.C., and Galbraith J.H., 2000. Leaf water relations and stomatal behavior of four allopatric Eucalyptus species planted in Mediterranean southwestern Australia. Tree Physiol. 20: 1157-1165.

Wingler A., 2002. The function of trehalose biosynthesis in plants. Phytochemistry 60: 437-440.

Zohar Y. and Schiller G., 1998. Growth and water use by selected seed sources of Eucalyptus under high water table and saline conditions. Agric. Ecosyst. Environ. 69: 265-277.

Zubrinich T.M., Loveys B., Gallasch S., Seekamp J.V., and Tyerman S.D., 2000. Tolerance of salinized floodplain conditions in a naturally occurring Eucalyptus hybrid related to lowered plant water potential. Tree Physiol. 20: 953-963. 